\title{
THE ACTUAL LEVEL OF INTERNATIONALIZATION OF ALBANIAN SMES AND THE MEASURE OF THEIR OVERALL PERFORMANCE
}

\author{
Emi Hoxholli ${ }^{*}$, Donika Kërçini ${ }^{1}$ \\ $1^{*}$ Faculty of Economics and Agrobusiness, Agricultural University of Tirana, Albania; \\ *Corresponding Author Emi Hoxholli, e-mail: emilihoxholli@yahoo.com; dkercini@ubt.edu.al;
}

Received December 2019; Accepted January 2020; Published February 2020;

DOI: https://doi.org/10.31407/ijees10.121

\begin{abstract}
The focus of our study is to determine the current state of internationalization of Albanian small and medium enterprises. Also, we aim to measure the level of success of Albanian small and medium enterprises that resulted to be internationally active. The study was conducted based on data collected by a survey in a sample of 200 Albanian small and medium enterprises (SMEs). These SMEs are located in 12 different counties of Albania and operate in different industries such as insurance, diary production, financial and accounting services, maintenance, clothes production, education etc. Of the total questionnaires distributed, only $81 \%$ of SMEs agreed to respond volutarly, while 19\% of them refused. The data collected were statistically elaborated with SPSS 20.00 and the finding were very satisfactory. Out of the total 164 SMEs that responded to the questionnaire, 84 of them were carring out international activities. Most of them used "export" as the main form of internationalization. For measuring the success of internationalization of Albanian SMEs, which resulted to be internationally active, we collected data about five different dimensions: intensity of international activity, object achievement, relative profitability, absolute profitability, management satisfaction. The combination of these five dimensions has given us the overall performance of SMEs. It resulted that the internationalization model adapted by Albanian SMEs was at a satisfactory level. The results are consistent if we compare them with the secondary data published by various organizations and institutions, as well as with the reality of the Albanian economy.
\end{abstract}

Keywords: Albania, SMEs, internationalization, performance, dimensions 